\title{
Kinetic Modeling of Texture and Color Changes During Thermal Treatment of Chicken Breast Meat
}

\author{
Rabeler, Felix; Feyissa, Aberham Hailu
}

Published in:

Food and Bioprocess Technology

Link to article, DOI:

$10.1007 / \mathrm{s} 11947-018-2123-4$

Publication date:

2018

Document Version

Peer reviewed version

Link back to DTU Orbit

Citation (APA):

Rabeler, F., \& Feyissa, A. H. (2018). Kinetic Modeling of Texture and Color Changes During Thermal Treatment of Chicken Breast Meat. Food and Bioprocess Technology, 11(8), 1495-1504. https://doi.org/10.1007/s11947018-2123-4

\section{General rights}

Copyright and moral rights for the publications made accessible in the public portal are retained by the authors and/or other copyright owners and it is a condition of accessing publications that users recognise and abide by the legal requirements associated with these rights.

- Users may download and print one copy of any publication from the public portal for the purpose of private study or research.

- You may not further distribute the material or use it for any profit-making activity or commercial gain

- You may freely distribute the URL identifying the publication in the public portal 
1 Kinetic modelling of texture and color changes during thermal treatment of chicken breast meat

3

4 Felix Rabeler*, Aberham Hailu Feyissa

5 Food Production Engineering, National Food Institute, Technical University of Denmark

6 (DTU), Denmark

$7 \quad{ }^{*}$ Corresponding author:

8 Søltofts Plads, 2800, Kgs. Lyngby, Denmark

$9 \quad$ Email address: felra@food.dtu.dk, Tel.: +45 45252531

ORCID: 0000-0001-8800-0280

Keywords: Poultry meat, quality changes, rate law, storage modulus, texture profile analyses (TPA), thermal processing

15

\section{Abstract}

Heat treatment is commonly applied as a primary method for ensuring the microbial safety of poultry meat and to enhance its palatability. Although texture and color of cooked chicken breast meat are important quality parameters for the consumers that need to be controlled during thermal processing, studies assessing the temperature-time-dependent quality changes

21 during thermal treatment are lacking. This work aims to investigate the texture and color

22 changes of chicken breast meat during thermal processing and to develop kinetic models that

23 describe these changes. We studied the storage modulus changes of chicken breast meat as

24 function of temperature. The storage modulus increases from $55^{\circ} \mathrm{C}$ until levelling off in an 
equilibrium value above $80{ }^{\circ} \mathrm{C}$, which was attributed to microstructure changes and described with a sigmoidal function. The changes in the texture (TPA) and color (CIE $L^{*} a^{*} b^{*}$ ) of chicken breast meat were measured as function of temperature and time. The texture and color parameters show a rise with heating time until reaching an equilibrium value, while the rate of change increased with temperature. Kinetic models that take the non-zero equilibrium into account were developed to describe the color (lightness) and texture (hardness, gumminess and chewiness) changes with heating time and temperature. The kinetic models provide a deeper insight into the mechanisms of texture and color changes during thermal treatment. They can be used to predict the texture and color development of chicken breast meat during thermal processing and, thus, help to optimize the process.

\section{Introduction}

The worldwide consumption of poultry meat has increased more than $30 \%$ over the last 10 years (OECD, 2018). Particularly, chicken breast meat is popular among consumers due to its relative low price compared to other meat products (e.g., beef and pork meat) and its low fat and high protein content (Guerrero-Legarreta and Hui, 2010; Magdelaine et al., 2008).

To ensure the safe consumption of chicken meat it should be heated at least to an internal temperature of $72{ }^{\circ} \mathrm{C}$ (Fsis, 2000). The heating leads to changes in the microstructure, texture and appearance of the chicken breast meat and may affect the acceptance by the consumers (Lawrie and Ledward, 2006).

The convective roasting (using hot air) is the most common heating method for chicken meat in professional kitchens and the large scale food industry, but also contact frying/grilling or the cooking in hot water is often applied (Guerrero-Legarreta and Hui, 2010; Lawrie and Ledward, 2006). Different studies show that the heating methods have different impact on the texture and color of poultry meat. Barbanti and Pasquini ( 2005) reported that hot air roasting leads to tougher poultry meat samples compared to the steam cooked samples, whereas Zell et 
al. ( 2010) reported that there is no significant difference in the texture of samples prepared by ohmic-heating and convectional heating. In these studies, the poultry meat samples were heated to different core temperatures and the change in the quality correlated with these temperatures. However, conventional heating methods (e.g., roasting in convection oven) lead to temperature gradients inside the meat which results in a non-uniform texture and color development.

The heating of poultry meat above $55^{\circ} \mathrm{C}$ leads to denaturation of myoglobin protein which results in a whitening of the meat (Guidi and Castigliego, 2010). At higher temperatures Maillard reactions take place resulting in a browning of the surface and the formation of flavor components (Brunton et al., 2002). Heating also induces transversely shrinkage of the meat fibers leading to wider gabs between them, followed by longitudinal shrinkage of the fibers, solubilization of connective tissue, muscle protein aggregation and gel formation (Tornberg, 2005). This leads to changes in the microstructure (denser matrix with compact fiber arrangements) and, thus, to a toughening of the meat (Wattanachant et al., 2005). Additionally, the protein denaturation reduces the water holding capacity which results in water loss during the cooking process (Micklander et al., 2002).

If the main physical factors that influence the quality of chicken meat are known, the thermal processing can be optimized to achieve the best possible quality of the meat product for the consumer. In this manner, kinetic modelling can provide a deeper understanding of the changes that occur during thermal processing and help to control and optimize the food quality (Haefner, 2005). For different muscle foods and vegetables, researchers showed that the quality degradation during thermal treatment can be described by a general rate law. The quality changes mainly follow a zero, first or second order kinetic (Ling et al., 2015; Van Boekel, 2008). To describe the relationship between the temperature and the reaction rate 
constant the common Arrhenius model is mostly used (Goncalves et al., 2007; Goñi and Salvadori, 2011; Ko et al., 2007; Kong et al., 2007).

There have been no systematic studies of the thermal changes of chicken meat quality with time and related kinetic models. Therefore, the aim of this study is to investigate the changes of chicken meat quality (texture and color) with time and temperature in order to develop kinetic models that describe these changes. We here present the effect of temperature and time on the texture (texture profile analyses - TPA) and color of chicken breast meat, as well as the effect of the temperature on the rheological properties of chicken breast meat.

\section{Kinetic modelling}

The irreversible change of a quality attribute $Q$ under isothermal condition can be described by the general rate law in the following form (Eq. (1)) (Levenspiel, 1999; Van Boekel, 1996):

$\frac{\partial Q}{\partial t}=-k Q^{n}$

where $k$ is the reaction rate constant $\left(\min ^{-1}[\mathrm{Q}]^{1-\mathrm{n}}\right), Q$ the quality attribute at time $t(\mathrm{~min})$ and $n$ the reaction order.

The temperature dependence of the reaction rate is mostly described by the Arrhenius equation (Eq. (2)):

$k=k_{0} \exp \left(-\frac{E_{a}}{R T}\right)$

where $k_{0}$ is the pre-exponential factor $\left(\min ^{-1}[\mathrm{Q}]^{1-\mathrm{n}}\right), E_{a}$ is the activation energy $(\mathrm{J} / \mathrm{mol}), R$ is the universal gas constant $(8.314 \mathrm{~J} /(\mathrm{mol} \mathrm{K}))$ and $T$ is the temperature in ${ }^{\circ} \mathrm{C}$.

Food quality changes are mostly reported to follow a zero, first or second order reaction. For isothermal conditions, integration of Eq. (1) gives: (Steinfeld et al., 1999; Van Boekel, 1996):

$\mathrm{Q}=Q_{0} * \exp (-k t)$

$\mathrm{n}=1$

$Q=\left(k t+\frac{1}{Q_{0}}\right)^{-1}$

$\mathrm{n}=2$ 
$$
Q_{0} \geq Q \geq Q_{\infty}
$$

106 and Eq. (4b) when the non-zero equilibrium is larger than the initial quality value (e.g.

107 toughening of the texture):

$108 \quad \frac{\partial Q}{\partial t}=k\left(Q_{\infty}-Q\right)^{n} \quad Q_{0} \leq Q \leq Q_{\infty}$

109 where $Q_{\infty}$ is the final non-zero equilibrium quality value after long heating times.

110 For isothermal conditions, integration of Eq. $4 \mathrm{~b}$ for a first and $n^{\text {th }}$ order leads to Eq. (5a) and 111 Eq. (5b), respectively:

112

$Q=Q_{\infty}-\left(Q_{\infty}-Q_{0}\right) * \exp (-k t)$

$Q=Q_{\infty}-\left[k t(n-1)+\left(Q_{\infty}-Q_{0}\right)^{1-n}\right]^{\frac{1}{1-n}}$

$n \neq 1$

114 For this study, Eq. (4b) is used to describe the quality changes (texture and color) of chicken

115 breast meat. Therefore, only the integrated forms of this equation are shown here for clarity.

116 For a first order reaction (Eq. (5a)) the same form as the fractional conversion model

117 (proposed by Rizvi and Tong (1997) for food quality changes) is obtained. Instead of

118 assuming the order of the reaction, it is, however, more appropriate to estimate the reaction

119 order $n$ together with the other kinetic parameters by solving and fitting the differential form

120 of the kinetic model (Eq. (4a) or Eq. (4b)) to the experimental data set (see section 3.4). 


\section{Materials and methods}

122

123

124

125

126

127

128

129

130

131

132

133

134

135

136

137

138

139

140

141

142

143

144

\subsection{Raw material}

Chilled $\left(4^{\circ} \mathrm{C}\right)$ chicken breast meat (without skin and bone) was obtained from a local supermarket (the same day as the experimental tests) and stored at $2{ }^{\circ} \mathrm{C}$ until preparation for the experiments.

\subsection{Rheological measurement}

For the rheological measurement the chicken meat was sliced along the fiber direction using an electrical meat slicer (AM 300, Minerva Omega group s.r.l., Italy) and circular samples with a height of $3 \pm 0.5 \mathrm{~mm}$ and a diameter of $35 \pm 1 \mathrm{~mm}$ were cut using a cork borer. The rheological characteristics of whole chicken breast meat were measured using a controlled stress rheometer (Haake Mars Rheometer, Type 006-0572; Thermo Fisher Scientific, USA) equipped with a $35 \mathrm{~mm}$ parallel plate attachment. Both plates were serrated to prevent any unwanted slipping and the rheometer was complemented with a temperature controller to precisely control $\left( \pm 0.5^{\circ} \mathrm{C}\right)$ and monitor the sample temperature. Dynamic rheological measurements were performed as described by Hashemi and Jafarpour (2016). One chicken disc sample was loaded between the plates and the sample sides covered with a thin layer of silicon oil to minimize the moisture evaporation with increasing temperature.

The sample was held at $25^{\circ} \mathrm{C}$ (starting temperature) for 5 min to ensure equilibrium. Afterwards, the sample temperature was increased stepwise from 25 to $85{ }^{\circ} \mathrm{C}$ with steps of 5 ${ }^{\circ} \mathrm{C}$ and holding times of 3 min at every temperature step before measurements (recording the data). The holding time was chosen as no further changes in the storage modulus were found for longer holding times (> 3min). All dynamic oscillating analyses were performed with a gap of $3 \mathrm{~mm}$ between the plates, a constant stress of $6 \mathrm{~Pa}$ and a constant frequency of $1 \mathrm{~Hz}$. The constant value for the stress was chosen within the linear viscoelastic region that was 
145 determined by performing stress sweeps $(0.1-1000 \mathrm{~Pa})$. Changes in the storage modulus G'

146 (elastic property), complex modulus G') (viscous property) and phase angle (ratio of loss

147 modulus to storage modulus) were recorded directly by the rheometer software (Haake

148 RheoWin 4).

\section{$149 \quad$ 3.3. Texture and color measurements}

150 For the texture and the color measurements disked shaped chicken meat samples with heights

151 of $6 \pm 0.5 \mathrm{~mm}$ and diameters of $21 \pm 1 \mathrm{~mm}$ and were prepared according to section 3.2. Thin

152 samples were used to ensure a fast heating to the desired temperature and to achieve a

153 uniform temperature within the chicken meat by reducing the time for internal heat transport.

154 The samples were heated in a thermostatic water bath with circulating water (SW22, Julabo

$155 \mathrm{GmbH}$, Germany) at 5 different temperatures (50, 65, 75, 85 and $\left.95^{\circ} \mathrm{C}\right)$ with varying heating

156 times (see Table 1). In order to control the sample temperature and moisture content, water as

157 a heating medium was chosen, as it allows a fast heating of the samples and avoids water loss

158 from the samples (the total moisture loss from the chicken meat was less than $6 \%$ ) (Thussu

159 and Datta, 2012).

160

161

162

Table 1: Heating the chicken meat samples at different water bath temperatures and cooking times.

\begin{tabular}{ll}
\hline $\begin{array}{l}\text { Water bath } \\
\text { temperature }\left[{ }^{\circ} \mathbf{C}\right]\end{array}$ & Cooking times \\
\hline $\mathbf{5 0}]$ & $200,400,600,800,1000,1200$ \\
$\mathbf{6 5}$ & $100,200,300,400,500,600,800,1000$ \\
$\mathbf{7 5}$ & $50,100,150,200,250,300,400,600,800$ \\
$\mathbf{8 5}$ & $50,100,150,200,250,300,400$ \\
$\mathbf{9 5}$ & $50,100,150,200,250,300,400$ \\
\hline
\end{tabular}

163 
The water bath was filled with demineralized water and preheated for 30 minutes to achieve

165 the desired temperatures and to ensure steady state conditions. The temperature of the water

166 bath as well as the sample temperature was monitored during the heat treatment using

167 thermocouples (type T). As the samples were thinly sliced, temperature equilibrium was

168 reached for every time step. After heating the samples in the water bath, they were

169 immediately placed in ice water for approximately 30 to 60 seconds to cool down the

170 samples. Subsequently, excess moisture was removed with a filter paper. The samples were

171 sealed in aluminum cups and stored for 2 hours at room temperature prior to further analysis.

\section{$172 \quad$ 3.3.1. Texture Profile Analysis}

173 The texture of raw and cooked chicken breast meat was analyzed using a TA.XTplus (Stable

174 Micro Systems, UK) texture analyzer with a $30 \mathrm{~kg}$ load cell. Double compression tests (TPA)

175 were performed according to the procedure described by Bourne (2002) with a cylindrical

176 probe of $50 \mathrm{~mm}$ diameter at room temperature. The probe contact area for all samples was

$177350 \mathrm{~mm}^{2}$ and the samples were compressed to a final strain of $40 \%$ with a test speed of 1

$178 \mathrm{~mm} / \mathrm{s}$. The time interval between the first and the second stroke was $5 \mathrm{~s}$. From the force-time

179 plot of the double compression test the TPA parameters hardness, cohesiveness, springiness,

180 gumminess and chewiness were calculated (Bourne, 2002).

\subsubsection{Color measurements}

182 The color of the chicken disc samples before and after cooking was measured using a hyper

183 spectral imaging system (VidometerLab 2, Videometer A/S, Denmark) which allows

184 measuring the color of the whole sample surface. The Videometer is widely used for imaging

185 food samples, for example for assessing the quality of minced beef after a frying process

186 (Daugaard et al., 2010). The device was calibrated radiometrically using a diffuse white as

187 well as dark target and geometrical calibration was performed with a geometric target. The

188 light setup of the device was then adjusted to chicken breast meat (Hansen, 1999). 
The sample was placed in a petri dish under the camera and an image was taken. Afterwards, the image was processed using the software package MATLAB (R2017a, The Mathworks Inc., MA, USA) and the color of the raw and cooked chicken meat samples was obtained in the $\mathrm{L}^{*} \mathrm{a} \mathrm{b}^{*}$ system. The $L^{*}$ defines the color lightness of the product (varies from 0 for white to 100 for black), $a^{*}$ indicates the color degree between red and green (a negative value indicates green color and a positive value indicates red color) and $b^{*}$ specifies the color degree between yellow and blue (negative values indicate blue colors and positive values yellow colors). The total color difference $\Delta E$ is defined by Eq. (9):

$\Delta E=\sqrt{\left(L-L_{0}\right)^{2}+\left(a^{*}-a^{*}{ }_{0}\right)^{2}+\left(b^{*}-b^{*}{ }_{0}\right)^{2}}$

with $L_{0}=66.95 \pm 1.62, a_{0} *=5.05 \pm 0.70$ and $b_{0} *=18.95 \pm 1.16$ the lightness, redness and yellowness of the raw chicken meat, respectively.

\subsection{Parameter estimation}

MATLAB (R2017a, The Mathworks Inc., MA, USA) was used to solve the ordinary differential equations that describe the quality changes (Eq. (4a) and Eq. (4b)) and to estimate the kinetic parameters. The parameters were estimated using non-linear least squares (Isqnonlin solver in MATLAB) (minimization of the sum of squared differences between the predicted ( $\left.Q_{\text {predicted }}\right)$ and measured ( $\left.Q_{\text {experiment }}\right)$ quality changes) and the bootstrap method with 1000 bootstrap samples (Efron, 1979). A detailed description of the Bootstrap method can be found in Sin and Gernaey (2016).

\subsection{Statistical analysis}

The precision of the calculated parameters was assessed by confidence intervals at $95 \%$.

Furthermore, the residuals randomness and normality was used to evaluate the quality of the regression. All experiments were repeated four times and the values from the rheological, texture and color measurements presented as mean values $\pm 95 \%$ confidence intervals. One- 
213 way ANOVA analyses and Tukey multiple range tests were performed to evaluate the

214 influence of the heating time and temperature on the texture and on the color changes of

215 chicken breast meat. Chi-square test was used to evaluate the goodness-of-fit. For all

216 statistical analyses a significance level of $\mathrm{P}<0.05$ was used.

\section{4. Results and discussion}

\subsection{Rheological changes}

219 The changes of the storage modulus $G^{\prime}$ and the phase angle $\gamma$ as function of the sample

220 temperature were recorded as shown in Fig.1. In the range of 25 and $55^{\circ} \mathrm{C}$ the storage

221 modulus does not change with the temperature. However, from 60 to $80{ }^{\circ} \mathrm{C}, G^{\prime}$ increases

222 sharply with increasing sample temperature, and reaches a maximum plateau (around $92 \mathrm{kPa}$ )

223 above $80^{\circ} \mathrm{C}$. The phase angle (the ratio of loss modulus to storage modulus) decreases over

224 the whole temperature range, while an accelerated decrease is observed for sample

225 temperatures above $50{ }^{\circ} \mathrm{C}$.

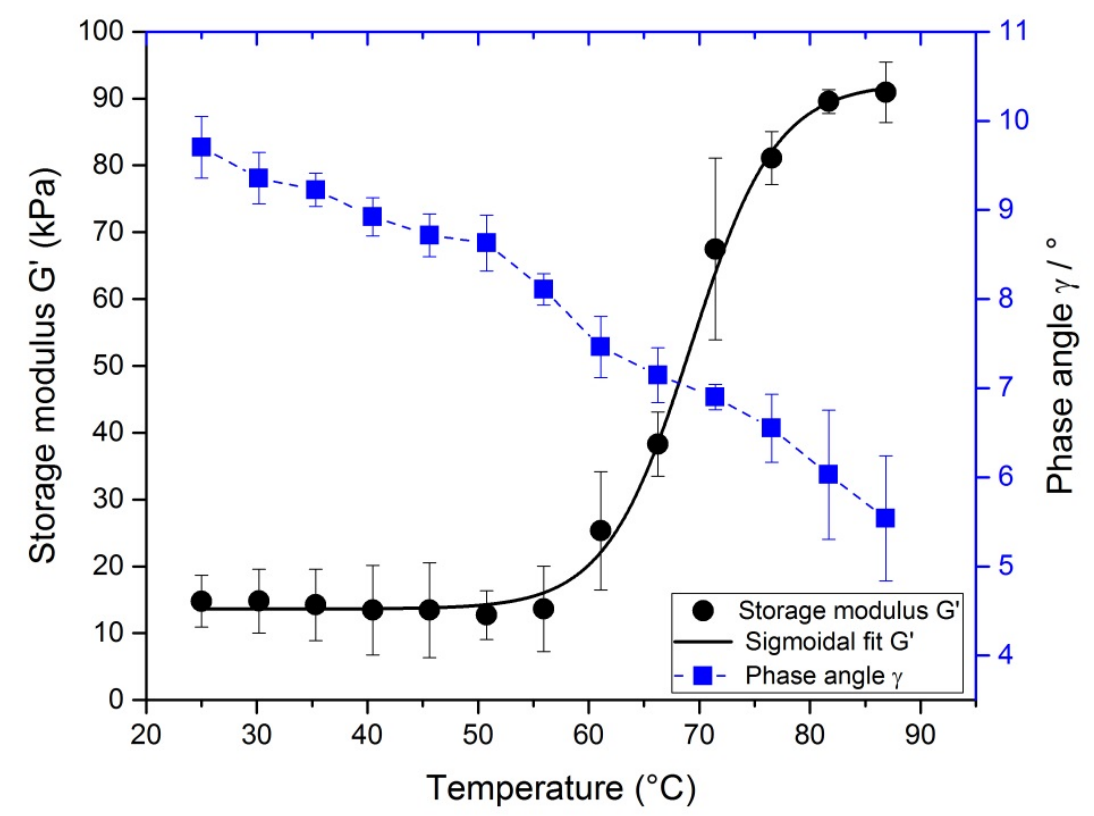

Fig. 1 Change of the storage modulus (kPa) and phase angle (degree) for chicken breast meat as function of sample temperature. Bars indicate the $95 \%$ confidence intervals $(n=4)$. 
230 Tornberg, (2005) observed a similar behavior of the storage modulus for whole beef meat 231 with rising temperature. However, the storage modulus for beef meat increases earlier (around $23250^{\circ} \mathrm{C}$ ) and also the maximum value is slightly lower (around $80 \mathrm{kPa}$ ) than for the chicken 233 breast meat $(92 \pm 2 \mathrm{kPa})$. The different behavior of chicken breast meat compared to whole 234 beef meat could be explained by an overall higher protein quality and quantity in chicken or 235 broiler meat (16 \% higher myofibrillar protein content) compared to beef meat (Montejano et 236 al., 1984; Mudalal et al., 2014; Tornberg, 2005).

237 The storage modulus indicates the change in the meat microstructure due to protein 238 denaturation that results in a toughening of the meat. Around a temperature of $62{ }^{\circ} \mathrm{C}$ myosin 239 starts to denature, followed by collagen at $70{ }^{\circ} \mathrm{C}$ and actin at $82{ }^{\circ} \mathrm{C}$ (Bircan and Barringer, 240 2002). This leads to structural changes inside the meat by longitudinal and transversal 241 shrinkage of meat fibers and solubilization of connective tissue. As a result, the meat becomes 242 more compact and harder leading to the increase of the storage modulus with rising 243 temperature (Tornberg, 2005).

244 The change of the storage modulus with temperature can be described as a sigmoidal curve 245 (solid line, Fig. 1) with the following equation:

$246 \quad G^{\prime}=G_{\text {max }}^{\prime}+\frac{\left(G^{\prime} 0_{0}-G^{\prime} \max \right)}{1+\exp \left(\frac{T-\bar{T}}{\Delta T}\right)}$

247 where $G^{\prime}{ }_{\max }=92 \pm 2 \mathrm{kPa}$ refers to the maximum storage modulus for chicken meat and $G^{\prime}{ }_{0}=$ $24813.5 \pm 1.3 \mathrm{kPa}$ to the initial storage modulus. $\bar{T}=69 \pm 1^{\circ} \mathrm{C}$ and $\Delta T=4 \pm 0.6^{\circ} \mathrm{C}$ are fitting 249 parameters that were estimated using the bootstrap method (see section 3.4).

\subsection{Texture changes}

251 The TPA parameters hardness $(\mathrm{Ha})$, gumminess $(\mathrm{Gu})$ and chewiness $(\mathrm{Cw})$ increase 252 significantly $(\mathrm{P}<0.01)$ with heating time (Fig. 2a-c). They all show a similar behavior with a 

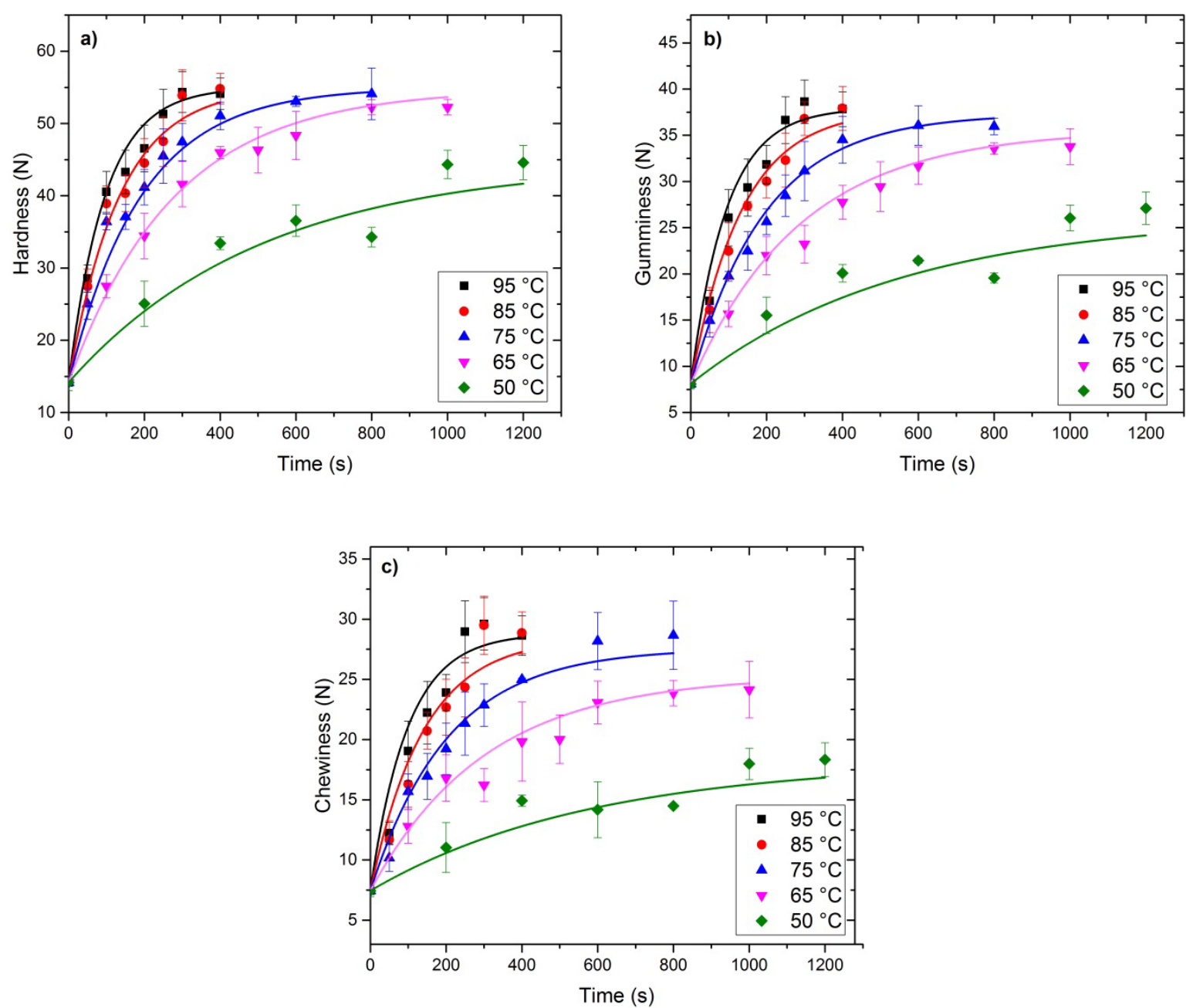

Fig. 2 Changes of the TPA parameters: a) hardness, b) gumminess and c) chewiness with heating time and sample temperature fitted with the modified rate law. Symbols with bars indicate the experimental mean values with the 95 $\%$ confidence intervals and the solid lines indicate the model fit $(n=4)$.

258 The changes of cohesiveness and springiness with temperature and time are summarized in

259 Table 2. The cohesiveness shows an increase with time until reaching an equilibrium value,

260 similar to hardness, gumminess and chewiness. The springiness shows a decrease in the

261 beginning (50 - $200 \mathrm{~s})$, after which it is also reaching an equilibrium value. However, no

262 significant influence of the temperature on the springiness was found. 


\begin{tabular}{|c|c|c|c|c|c|c|c|c|c|c|}
\hline \multirow{3}{*}{$\begin{array}{l}\text { Time } \\
\text { [s] }\end{array}$} & \multicolumn{5}{|c|}{ Cohesiveness } & \multicolumn{5}{|c|}{ Springiness } \\
\hline & \multicolumn{5}{|c|}{ Temperature $\left[{ }^{\circ} \mathrm{C}\right]$} & \multicolumn{5}{|c|}{ Temperature $\left[{ }^{\circ} \mathrm{C}\right]$} \\
\hline & 50 & 65 & 75 & 85 & 95 & 50 & 65 & 75 & 85 & 95 \\
\hline 0 & $\begin{array}{c}0.573 \\
\pm 0.038\end{array}$ & $\begin{array}{c}0.573 \\
\pm 0.038\end{array}$ & $\begin{array}{c}0.573 \\
\pm 0.038\end{array}$ & $\begin{array}{c}0.573 \\
\pm 0.038\end{array}$ & $\begin{array}{c}0.573 \\
\pm 0.038\end{array}$ & $\begin{array}{r}91.98 \\
\pm 1.57\end{array}$ & $\begin{array}{r}91.98 \\
\pm 1.57\end{array}$ & $\begin{array}{r}91.98 \\
\pm 1.57\end{array}$ & $\begin{array}{r}91.98 \\
\pm 1.57\end{array}$ & $\begin{array}{r}91.98 \\
\pm 1.57\end{array}$ \\
\hline 50 & - & - & $\begin{array}{c}0.596 \\
\pm 0.028\end{array}$ & $\begin{array}{c}0.589 \\
\pm 0.021\end{array}$ & $\begin{array}{c}0.598 \\
\pm 0.001\end{array}$ & - & - & $\begin{array}{r}68.38 \\
\pm 5.37\end{array}$ & $\begin{array}{r}72.80 \\
\pm 2.78\end{array}$ & $\begin{array}{r}71.60 \\
\pm 0.94\end{array}$ \\
\hline 100 & - & $\begin{array}{c}0.574 \\
\pm 0.015\end{array}$ & $\begin{array}{c}0.543 \\
\pm 0.024\end{array}$ & $\begin{array}{c}0.578 \\
\pm 0.038\end{array}$ & $\begin{array}{c}0.644 \\
\pm 0.031\end{array}$ & - & $\begin{array}{r}83.02 \\
\pm 1.55\end{array}$ & $\begin{array}{r}79.32 \\
\pm 5.18\end{array}$ & $\begin{array}{r}72.18 \\
\pm 3.59\end{array}$ & $\begin{array}{l}73.08 \\
\pm 3.73\end{array}$ \\
\hline 150 & - & - & $\begin{array}{c}0.606 \\
\pm 0.039\end{array}$ & $\begin{array}{c}0.683 \\
\pm 0.046\end{array}$ & $\begin{array}{c}0.675 \\
\pm 0.031\end{array}$ & - & - & $\begin{array}{r}75.30 \\
\pm 3.53\end{array}$ & $\begin{array}{r}75.71 \\
\pm 4.98\end{array}$ & $\begin{array}{r}75.08 \\
\pm 5.18\end{array}$ \\
\hline 200 & $\begin{array}{c}0.619 \\
\pm 0.013\end{array}$ & $\begin{array}{c}0.599 \\
\pm 0.026\end{array}$ & $\begin{array}{c}0.624 \\
\pm 0.011\end{array}$ & $\begin{array}{c}0.676 \\
\pm 0.033\end{array}$ & $\begin{array}{c}0.685 \\
\pm 0.038\end{array}$ & $\begin{array}{l}70.72 \\
\pm 5.4\end{array}$ & $\begin{array}{r}76.71 \\
\pm 3.02\end{array}$ & $\begin{array}{r}74.91 \\
\pm 2.15\end{array}$ & $\begin{array}{l}75.60 \\
\pm 5.64\end{array}$ & $\begin{array}{r}75.24 \\
\pm 3.86\end{array}$ \\
\hline 250 & - & - & $\begin{array}{c}0.626 \\
\pm 0.001\end{array}$ & $\begin{array}{c}0.681 \\
\pm 0.036\end{array}$ & $\begin{array}{c}0.714 \\
\pm 0.031\end{array}$ & - & - & $\begin{array}{r}84.46 \\
\pm 3.92\end{array}$ & $\begin{array}{r}75.20 \\
\pm 5.50\end{array}$ & $\begin{array}{r}78.65 \\
\pm 3.62\end{array}$ \\
\hline 300 & - & $\begin{array}{c}0.604 \\
\pm 0.060\end{array}$ & $\begin{array}{c}0.642 \\
\pm 0.011 \\
3\end{array}$ & $\begin{array}{c}0.740 \\
\pm 0.048\end{array}$ & $\begin{array}{c}0.712 \\
\pm 0.042\end{array}$ & - & $\begin{array}{r}66.56 \\
\pm 5.57\end{array}$ & $\begin{array}{r}70.21 \\
\pm 6.32\end{array}$ & $\begin{array}{l}81.14 \\
\pm 2.50\end{array}$ & $\begin{array}{r}76.65 \\
\pm 3.84\end{array}$ \\
\hline 400 & $\begin{array}{c}0.601 \\
\pm 0.038\end{array}$ & $\begin{array}{c}0.623 \\
\pm 0.029\end{array}$ & $\begin{array}{c}0.677 \\
\pm 0.021\end{array}$ & $\begin{array}{c}0.692 \\
\pm 0.036\end{array}$ & $\begin{array}{c}0.699 \\
\pm 0.035\end{array}$ & $\begin{array}{r}74.45 \\
\pm 1.29\end{array}$ & $\begin{array}{r}78.60 \\
\pm 0.74\end{array}$ & $\begin{array}{l}82.52 \\
\pm 6.93\end{array}$ & $\begin{array}{r}76.11 \\
\pm 3.00\end{array}$ & $\begin{array}{r}71.71 \\
\pm 3.92\end{array}$ \\
\hline 600 & $\begin{array}{c}0.587 \\
\pm 0.027\end{array}$ & $\begin{array}{c}0.655 \\
\pm 0.023\end{array}$ & $\begin{array}{c}0.695 \\
\pm 0.037\end{array}$ & - & - & $\begin{array}{r}66.08 \\
\pm 6.95\end{array}$ & $\begin{array}{r}72.98 \\
\pm 2.00\end{array}$ & $\begin{array}{l}79.44 \\
\pm 7.34\end{array}$ & - & - \\
\hline 800 & $\begin{array}{c}0.571 \\
\pm 0.007\end{array}$ & $\begin{array}{c}0.652 \\
\pm 0.044\end{array}$ & $\begin{array}{c}0.709 \\
\pm 0.013\end{array}$ & - & - & $\begin{array}{l}74.07 \\
\pm 1.64\end{array}$ & $\begin{array}{r}73.53 \\
\pm 3.98\end{array}$ & $\begin{array}{l}76.62 \\
\pm 5.81\end{array}$ & - & - \\
\hline 1000 & $\begin{array}{c}0.588 \\
\pm 0.021\end{array}$ & $\begin{array}{c}0.646 \\
\pm 0.036\end{array}$ & - & - & - & $\begin{array}{r}68.96 \\
\pm 1.43\end{array}$ & $\begin{array}{r}69.02 \\
\pm 5.27\end{array}$ & - & - & - \\
\hline 1200 & $\begin{array}{c}0.605 \\
\pm 0.015\end{array}$ & - & - & - & - & $\begin{array}{r}78.59 \\
\pm 4.00\end{array}$ & - & - & - & - \\
\hline
\end{tabular}

267 Under thermal treatment the meat proteins denature stepwise with different mechanisms for

268 each temperature interval. In the temperature range from 40 to $50{ }^{\circ} \mathrm{C}$, collagen fibers partially

269 denature and straighten, leading to a first toughening of the meat (Lewis and Purslow, 1989).

270 Further temperature increase leads to denaturation and shrinkage of myofibrillar proteins as

271 well as dehydration and shrinkage of actomyosin, resulting in a supplementary toughening of

272 the meat (Christensen et al., 2000; Tornberg, 2005). The rate of the protein denaturation 
273 increases with increasing temperature of the sample, resulting in a faster toughening of the

274 meat at higher temperatures (Bailey and Light, 1989).

275 Wattanachant et al. (2005) investigated the change of the chicken meat microstructure at 276 different core temperatures. They showed that the microstructure of chicken meat became 277 denser with more compact fiber arrangements at increasing internal temperature. However, no 278 further toughening of the texture above $80^{\circ} \mathrm{C}$ was observed. Furthermore, the storage 279 modulus of chicken breast meat, $G$ ', is reaching an equilibrium value for temperatures above $28080^{\circ} \mathrm{C}$ (see Fig. 1, section 4.1), indicating no further changes in the microstructure due to 281 protein denaturation. These observations could explain why there is no significant difference 282 between the slope as well as the equilibrium values of hardness $(\mathrm{P}>0.05)$, gumminess $(\mathrm{P}>$ $2830.05)$ and chewiness $(\mathrm{P}>0.05)$ for sample temperatures of 85 to $95{ }^{\circ} \mathrm{C}$.

284 For the TPA parameters hardness, gumminess and chewiness (Fig. 2a-c) a small plateau is 285 visible before reaching the equilibrium value especially at 50 and $65^{\circ} \mathrm{C}$. Feyissa et al. (2013) 286 showed that the microstructure of meat is changing dramatically during the cooking. Protein 287 denaturation leads to pore formation, decrease in the water holding capacity (WHC) and water 288 migration into the spaces between the muscle fibers. For chicken breast meat, Van der Sman 289 (2013) showed that the WHC is a function of temperature. The unbound water could work as 290 a plasticizer leading to the small plateau before further denaturation results in the further 291 toughening of the meat until the equilibrium is reached (Hughes et al., 2014).

292 Eq. (4b) ( $Q_{\infty}$ is larger than the initial value $\left.Q_{0}\right)$ was used to model the changes in the TPA 293 parameters hardness, gumminess and chewiness with temperature and time. The Arrhenius 294 equation (Eq. (2)) is used to describe the temperature dependence of the rate constant $k$. By 295 solving and fitting Eq. (4b) to the experimental data set the equilibrium values $Q_{\infty}$, the 296 activation energies $E_{a}$, the pre-exponential factors $k_{0}$ and the reaction orders $n$ were estimated 297 (see section 3.4). 
298 The obtained individual equilibrium values for hardness $\left(H a_{\infty}\right)$, gumminess $\left(G u_{\infty}\right)$ and

299 chewiness $\left(C w_{\infty}\right)$ vary with temperature (see Fig. 2a-c) and are described by Eq. (11a-c):

Hardness $\quad \mathrm{Ha}_{\infty}(\mathrm{T})=Q_{\max }+\frac{Q_{0}-Q_{\max }}{1+\exp \left(\frac{T-\bar{T}}{\Delta T}\right)}$

Gumminess $\quad \mathrm{Gu}_{\infty}(\mathrm{T})=Q_{\max }+\frac{Q_{0}-Q_{\max }}{1+\exp \left(\frac{T-\bar{T}}{\Delta T}\right)}$

Chewiness

$$
\mathrm{Cw}_{\infty}(\mathrm{T})=Q_{\max }+\frac{Q_{0}-Q_{\max }}{1+\exp \left(\frac{T-\bar{T}}{\Delta T}\right)}
$$

301 where $Q_{\max }, \bar{T}$ and $\Delta T$ are fitting parameters. The corresponding parameters are presented in

302 Table 3. The changes of the equilibrium values with temperature show a similar behavior as

303 the change of the storage modulus with temperature (see Fig. 1). This indicates that the degree

304 of structural changes due to protein denaturation is responsible for the change in the

305 equilibrium value with temperature.

Table 3: Estimated parameters for Eq. (7a-c) to describe the equilibrium of hardness, gumminess and chewiness of chicken meat as a function of temperature.

\begin{tabular}{l|cccc}
\hline & $\mathbf{Q}_{\max }[\mathbf{N}]$ & $\mathbf{Q}_{\mathbf{0}}[\mathbf{N}]$ & $\overline{\mathbf{T}}\left[{ }^{\circ} \mathbf{C}\right]$ & $\Delta \mathbf{T}\left[{ }^{\circ} \mathbf{C}\right]$ \\
\hline Hardness Ha $\infty$ & $55.2 \pm 3.5$ & $14 \pm 1.4$ & $45 \pm 1.5$ & $4 \pm 1.1$ \\
Gumminess Gu$\infty$ & $38.6 \pm 2.2$ & $7 \pm 1.1$ & $47 \pm 2.1$ & $8 \pm 1.4$ \\
Chewiness $\mathbf{C w}_{\infty}$ & $28.5 \pm 1.7$ & $6.9 \pm 1.5$ & $50 \pm 2.9$ & $10 \pm 2.1$ \\
\hline
\end{tabular}


The results for the estimated activation energies $E_{a}$, pre-exponential factors $k_{0}$ and reaction

312 orders $n$ are summarized in Table 4 with the corresponding $95 \%$ confidence intervals. As

313 shown in Fig. 2a-c the developed kinetic models (solid lines) can describe the changes in

314 hardness, gumminess and chewiness with time and temperature $\left(X_{\text {hardness }}^{2}=4.05, X_{\text {gumminess }}^{2}=\right.$

3.15, $\left.X_{\text {chewiness }}^{2}=39.67, \mathrm{P}>0.05\right)$.

Table 4: Obtained kinetic parameters for the change of the TPA parameters (hardness, gumminess and chewiness) of

\begin{tabular}{lcccc}
\hline Texture index & $\mathbf{n}$ & $\mathbf{E a}(\mathbf{k J} / \mathbf{m o l})$ & $\mathbf{k o ~}_{\left(\mathbf{m i n}^{\mathbf{- 1}}[\mathbf{Q}]^{1-\mathbf{n}}\right) \mathbf{x} \mathbf{1 0}^{-\mathbf{3}}}$ & $\boldsymbol{X}^{\mathbf{2}}$ \\
\hline Hardness (N) & $1.12 \pm 0.11$ & $39.3 \pm 2.7$ & $196 \pm 8.3$ & 4.05 \\
Gumminess (N) & $0.98 \pm 0.06$ & $35.9 \pm 2.2$ & $64 \pm 4.1$ & 3.15 \\
Chewiness (N) & $1.01 \pm 0.09$ & $44.6 \pm 3.5$ & $773 \pm 29$ & 39.67 \\
\hline
\end{tabular}

321 The obtained activation energies $E_{a}$ for hardness, gumminess and chewiness are $39.3 \pm 2.7$, $32235.9 \pm 2.2$ and $44.6 \pm 3.5 \mathrm{~kJ} / \mathrm{mol}$, respectively. The values are in the same range as reported 323 by other authors for textural changes of different foods (10 - $100 \mathrm{~kJ} / \mathrm{mol})$ (Ling et al., 2015):

324 for example mussels (65 kJ/mol) (Ovissipour et al., 2013), pumpkin (72 kJ/mol) (Goncalves 325 et al., 2007) or mushrooms (15 kJ/kg) (Ko et al., 2007).

\subsection{Color changes}

327 Fig. 3a-d show the changes of chicken meat color (CIE $L^{*}, a^{*}, b^{*}$ ) with heating time.

328 During thermal treatment in a moist surrounding chicken breast meat becomes white, leading

329 to significant changes in the color values compared to the raw chicken meat color. For

330 temperatures of 75 to $95{ }^{\circ} \mathrm{C}$ the values of lightness $L^{*}$ and total color difference $\Delta E$ (Eq. (1))

331 rise rapidly until levelling off and reaching an equilibrium value of $87 \pm 0.72$ and $21 \pm 0.67$,

332 respectively (Fig. 3a and 3b). However, for 85 and $95^{\circ} \mathrm{C}$ no significant difference $\left.(\mathrm{P}<0.01)\right)$

333 was found between the slopes of the curves. For temperatures of 65 and $50{ }^{\circ} \mathrm{C}$ the slope of the 

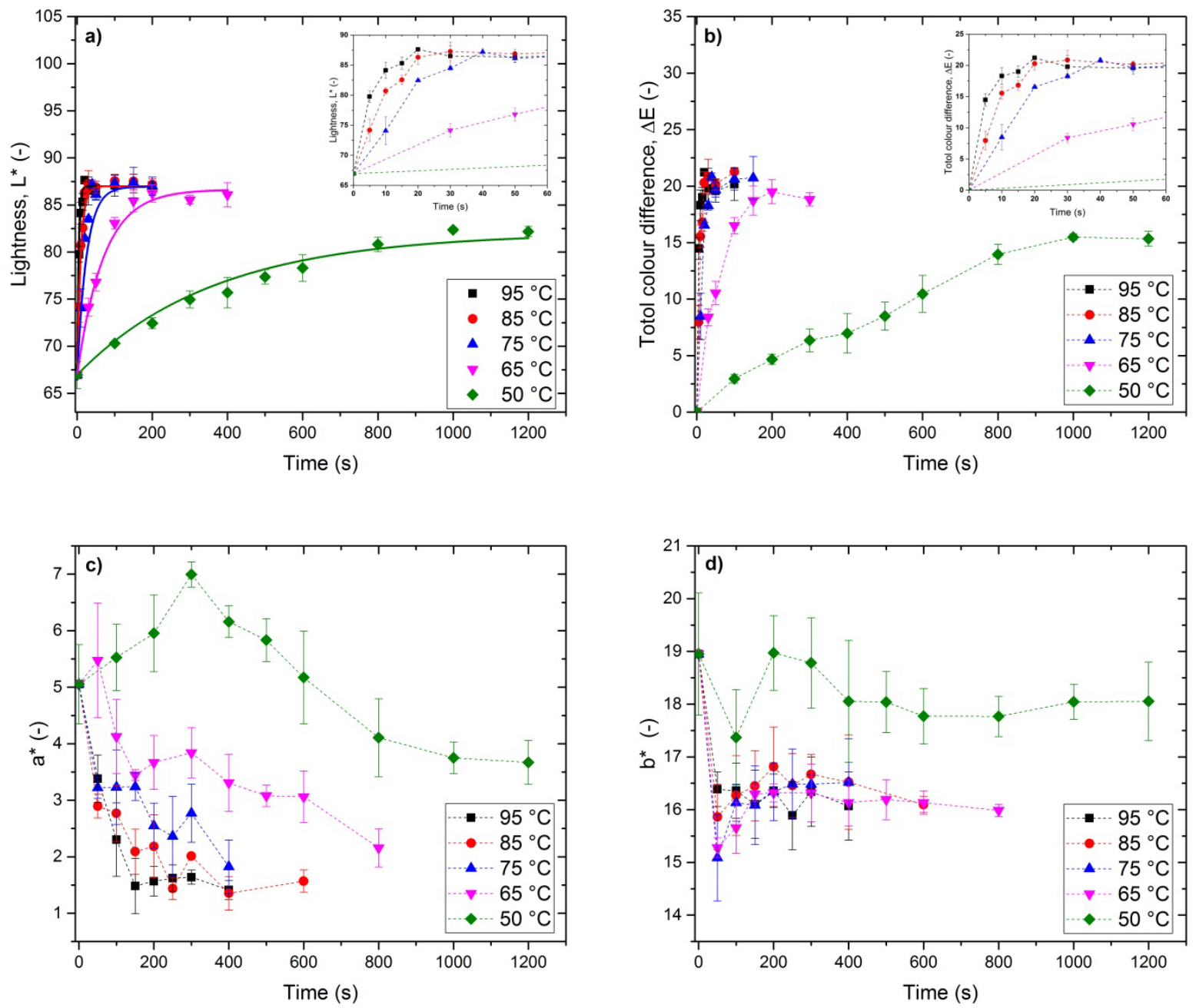

Fig. 3 Changes of the chicken meat color with heating time and sample temperature: a) lightness $\left(\mathrm{L}^{*}\right)$, b) total color difference $(\Delta E)$, c) redness $\left(a^{*}\right)$ and $\left.d\right)$ yellowness $\left(b^{*}\right)$. Symbols with bars indicate the experimental mean values with the $95 \%$ confidence intervals $(n=4)$. The solid line in a) shows the model fit.

338 For temperatures of 65 to $95^{\circ} \mathrm{C}$, the $a^{*}$ and $b^{*}$ values decrease with time until reaching an

339 equilibrium, while the slopes of the curves increase with rising temperature. At $50{ }^{\circ} \mathrm{C}$ the $a^{*}$

340 value first increases before it is decreasing and levelling off to an equilibrium value (Fig. 3c).

341 The $b^{*}$ value is first slightly decreasing at $50{ }^{\circ} \mathrm{C}$ until reaching an equilibrium which is just

342 marginally beneath the $b^{*}$ value for the raw sample (Fig. 3d). 
343 During the heating heme proteins (hemoglobin and myoglobin) denature resulting in the

344 whitening of the muscle. Hemoglobin and myoglobin are relatively heat stable and

345 completely denature at temperatures around 65 to $80{ }^{\circ} \mathrm{C}$ while the rate and degree of

346 denaturation increases with temperature (Lawrie and Ledward, 2006; Martens et al., 1982).

347 For temperatures below the denaturation temperature of myoglobin $\left(<65^{\circ} \mathrm{C}\right)$ the color

348 change cannot be explained just by heme protein denaturation. However, structural changes,

349 initiated from the denaturation of myofibrillar proteins and other structural proteins, could

350 lead to a higher light scattering and optical masking of heme-proteins causing a lighter

351 product (Hughes et al., 2014; Martens et al., 1982).

352 The changes in the lightness $L^{*}$ of chicken breast meat for the tested temperature $\left(50-95^{\circ} \mathrm{C}\right)$

353 and time range (50 - 1200 s) were modeled using Eq. (4b) ( $Q_{\infty}$ is larger than the initial value

$354 Q_{0}$ ). The Arrhenius equation (Eq. (2)) is used to describe the temperature dependence of the

355 rate constant. By solving and fitting Eq. (4b) to the experimental data set, the activation

356 energy $E_{a}$, the pre-exponential factor $k_{0}$ as well as the reaction order $n$ were estimated (see

357 section 3.4). The estimated value for the activation energy, pre-exponential factor $k_{0}$ and

358 reaction order $n$ are $101.59 \pm 7.83 \mathrm{~kJ} / \mathrm{mol}, 2.65 \times 10^{15} \pm 1.97 \times 10^{14} \mathrm{~min}^{-1}$ and $1.1 \pm 0.06$,

359 respectively. The developed kinetic model (solid lines in Fig. 3a) can describe the change in

360 lightness with time and temperature $\left(X^{2}\right.$ lightness $\left.=1.29, \mathrm{P}>0.05\right)$.

361 The obtained $E_{a}$ value for the change in the lightness $L^{*}(101.59 \pm 7.83 \mathrm{~kJ} / \mathrm{mol})$ is within the

362 same range reported for the color changes of different muscle foods and vegetables (80 to 120

$363 \mathrm{~kJ} / \mathrm{mol}$ ) (Ling et al., 2015): salmon (88 kJ/mol) (Kong et al., 2007), beef (81 kJ/mol) (Goñi

364 and Salvadori, 2011) or pumpkin (120 kJ/mol) (Goncalves et al., 2007).

\section{Conclusion}

366 In this study, we developed kinetic models that describe the texture and color changes of

367 chicken breast meat as function of temperature and heating time. The TPA parameters 
368 hardness, gumminess and chewiness as well as the color parameter lightness increase with

369 heating time until reaching an equilibrium value. The rate of the texture and color changes

370 increases with temperature due to a faster protein denaturation. The color and texture changes

371 were fitted to a modified rate law that takes the non-zero equilibrium into account. The

372 resulting kinetic models well describe the measured quality changes. Moreover, the change in

373 the storage modulus of chicken breast meat with temperature was evaluated and the

374 development was well described with a sigmoidal function. The storage modulus increases

375 sharply between 60 and $80{ }^{\circ} \mathrm{C}$ due to heat-induced protein denaturation which leads to

376 changes in the microstructure of the chicken meat.

377 Overall, the developed kinetic models and rheological properties provide a deeper

378 understanding of the mechanism of the quality changes during the thermal processing of

379 chicken breast meat. These can be coupled to physical based models (such as heat and mass

380 transfer) enabling the prediction of quality changes during thermal processing. This means

381 that the spatial quality attributes can be predicted from the local temperature development

382 with time, thus, helping to optimize the process settings for thermal treatments of foods to

383 obtain the optimal quality for the consumer. 


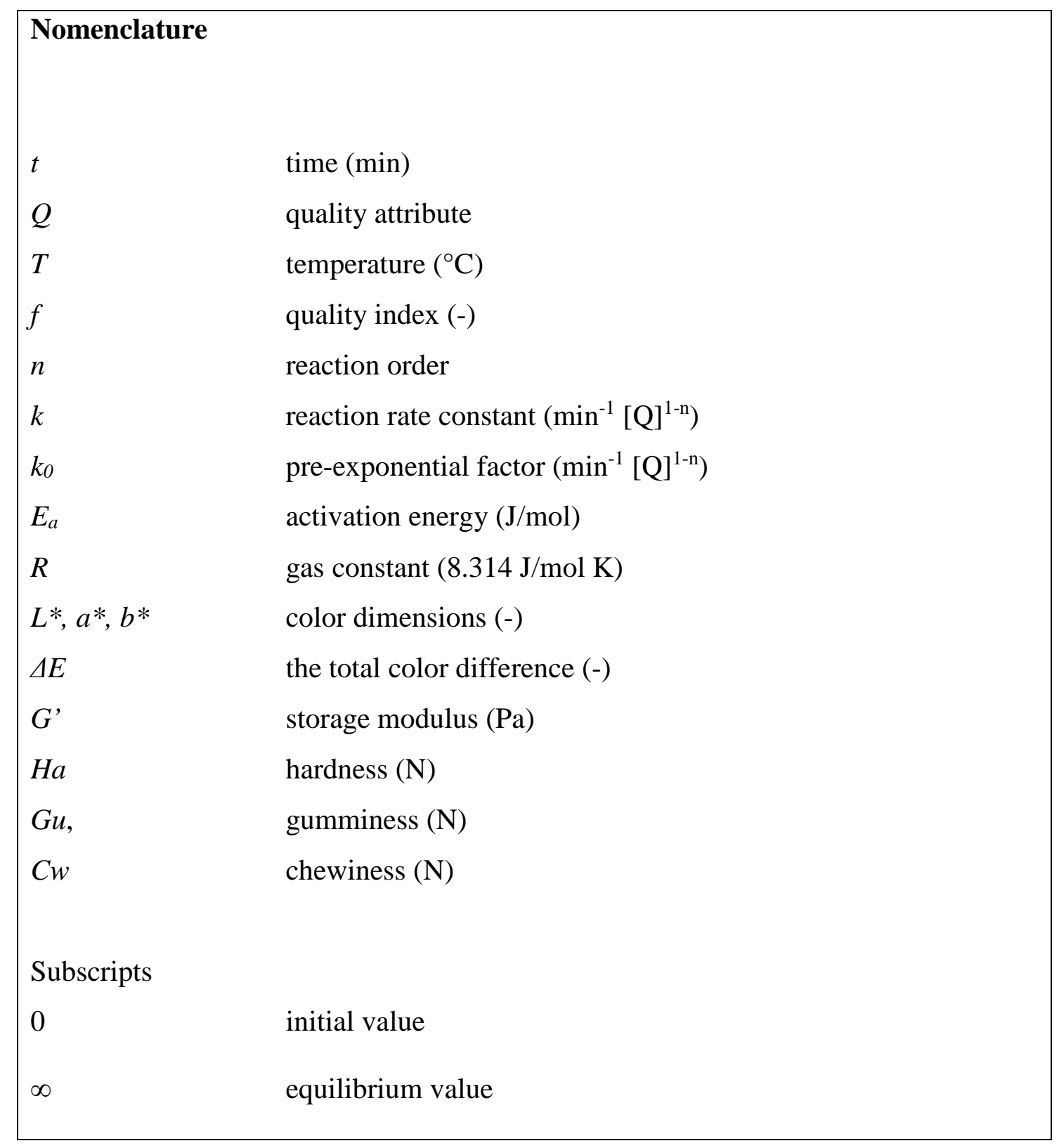




\section{References}

Bailey, A.J., Light, N.D., 1989. Connective Tissue in Meat and Meat Products. Elsevier applied science.

Barbanti, D., Pasquini, M., 2005. Influence of cooking conditions on cooking loss and tenderness of raw and marinated chicken breast meat. LWT - Food Sci. Technol. 38, 895-901. doi:10.1016/j.lwt.2004.08.017

Bircan, C., Barringer, S. a., 2002. Determination of Protein Denaturation of Muscle Foods Using the Dielectric Properties. J. Food Sci. 67, 202-205. doi:10.1111/j.13652621.2002.tb11384.x

Bourne, M.C., 2002. Principles of Objective Texture Measurement. Food Texture Viscosity Concept Meas. 2nd Ed.

Brunton, N.P., Cronin, D.A., Monahan, F.J., 2002. Volatile components associated with freshly cooked and oxidized off-flavours in Turkey breast meat. Flavour Fragr. J. 17, 327-334. doi:10.1002/ffj.1087

Christensen, M., Purslow, P.P., Larsen, L.M., 2000. The effect of cooking temperature on mechanical properties of whole meat, single muscle fibres and perimysial connective tissue. Meat Sci. 55, 301-307. doi:10.1016/S0309-1740(99)00157-6

Daugaard, S.B., Adler-Nissen, J., Carstensen, J.M., 2010. New vision technology for multidimensional quality monitoring of continuous frying of meat. Food Control 21, 626-632. doi:10.1016/j.foodcont.2009.09.007

Efron, B., 1979. Bootstrap Methods: Another look at the Jacknife. Ann. Stat. 7.

Feyissa, A.H., Gernaey, K. V., Adler-Nissen, J., 2013. 3D modelling of coupled mass and heat transfer of a convection-oven roasting process. Meat Sci. 93, 810-820. doi:10.1016/j.meatsci.2012.12.003

Fsis, U., 2000. Chicken from Farm to Table 1-8. 
Goncalves, E.M., Pinheiro, J., Abreu, M., Brand??o, T.R.S., Silva, C.L.M., 2007. Modelling

413

414

415

416

417

418

419

420

421

422

423

424

425

426

427

428

429

430

431

432

433

434

435

436

the kinetics of peroxidase inactivation, colour and texture changes of pumpkin

(Cucurbita maxima L.) during blanching. J. Food Eng. 81, 693-701.

doi:10.1016/j.jfoodeng.2007.01.011

Goñi, S.M., Salvadori, V.O., 2011. Kinetic modelling of colour changes during beef roasting. Procedia Food Sci. 1, 1039-1044. doi:10.1016/j.profoo.2011.09.155

Guerrero-Legarreta, I., Hui, Y.H., 2010. Handbook of Poultry Science and Technology, Volume 2: ed. John Wiley \& Sons, Inc. doi:10.1002/9780470504475

Guidi, A., Castigliego, L., 2010. Poultry Meat Color. Handb. Poult. Sci. Technol. Vol. 2 2, 359-388. doi:10.1002/9780470504475.ch25

Haefner, J.W., 2005. Modeling Biological Systems: Principles and Applications. SpringerVerlag, New York. doi:10.1007/b106568

Hansen, J.F., 1999. On chromatic and geometrical calibration. Technical University of Denmark.

Hashemi, A., Jafarpour, A., 2016. Rheological and microstructural properties of beef sausage batter formulated with fish fillet mince. J. Food Sci. Technol. 53, 601-610. doi:10.1007/s13197-015-2052-4

Hughes, J.M., Oiseth, S.K., Purslow, P.P., Warner, R.D., 2014. A structural approach to understanding the interactions between colour, water-holding capacity and tenderness. Meat Sci. 98, 520-532. doi:10.1016/j.meatsci.2014.05.022

Ko, W.C., Liu, W.C., Tsang, Y.T., Hsieh, C.W., 2007. Kinetics of winter mushrooms (Flammulina velutipes) microstructure and quality changes during thermal processing. J. Food Eng. 81, 587-598. doi:10.1016/j.jfoodeng.2006.12.009

Kong, F., Tang, J., Rasco, B., Crapo, C., 2007. Kinetics of salmon quality changes during thermal processing. J. Food Eng. 83, 510-520. doi:10.1016/j.jfoodeng.2007.04.002 
Lawrie, R.A., Ledward, D.A., 2006. Lawrie’s meat science.

Levenspiel, O., 1999. Chemical reaction engineering, Ind. Eng. Chem. Res.

$$
\text { doi:10.1021/ie990488g }
$$

Lewis, G.J., Purslow, P.P., 1989. The strength and stiffness of perimysial connective tissue isolated from cooked beef muscle. Meat Sci. 26, 255-269. doi:10.1016/0309-

$$
\text { 1740(89)90011-9 }
$$

Ling, B., Tang, J., Kong, F., Mitcham, E.J., Wang, S., 2015. Kinetics of Food Quality Changes During Thermal Processing: a Review. Food Bioprocess Technol. 8, 343-358. doi:10.1007/s11947-014-1398-3

Magdelaine, P., Spiess, M.P., Valceschini, E., 2008. Poultry meat consumption trends in Europe. Worlds. Poult. Sci. J. 64, 53-63. doi:10.1017/S0043933907001717

Martens, H., Stabursvik, E., Martens, M., 1982. Texture and Color Changes in Meat during Cooking Related to Thermal-Denaturation of Muscle Proteins. J. Texture Stud. 13, 291309.

Micklander, E., Peshlov, B., Purslow, P.P., Engelsen, S.B., 2002. NMR-cooking: Monitoring the changes in meat during cooking by low-field 1H-NMR. Trends Food Sci. Technol. 13, 341-346. doi:10.1016/S0924-2244(02)00163-2

Montejano, J.G., Hamann, D.D., Lanier, T.C., 1984. Thermally induced gelation of selected comminuted muscle systems-rheological changes during processing, final strengths and microstructure. J. Food Sci. 49, 1496-1505. doi:10.1111/j.1365-2621.1984.tb12830.x

Mudalal, S., Babini, E., Cavani, C., Petracci, M., 2014. Quantity and functionality of protein fractions in chicken breast fillets affected by white striping. Poult. Sci. 93, 2108-16. doi:10.3382/ps.2014-03911

OECD, 2018. Meat consumption (indicator). doi:10.1787/fa290fd0-en

Ovissipour, M., Rasco, B., Tang, J., Sablani, S.S., 2013. Kinetics of quality changes in whole 
blue mussel (Mytilus edulis) during pasteurization. Food Res. Int. 53, 141-148. doi:10.1016/j.foodres.2013.04.029

Rizvi, a F., Tong, C.H., 1997. Fractional Conversion for Determining Texture Degradation Kinetics of Vegetables. J. Food Sci. 62, 1-7. doi:10.1111/j.1365-2621.1997.tb04356.x

Sin, G., Gernaey, K. V., 2016. DATA HANDLING AND PARAMETER ESTIMATION, in: Experimental Methods In Wastewater Treatment. IWA Publishing, London, UK.

Steinfeld, J.I., Francisco, J.S., Hase, W.L., 1999. Chemical kinetics and dynamics. Prentice Hall.

Thussu, S., Datta, A.K., 2012. Texture prediction during deep frying: A mechanistic approach. J. Food Eng. 108, 111-121. doi:10.1016/j.jfoodeng.2011.07.017

Tornberg, E., 2005. Effects of heat on meat proteins - Implications on structure and quality of meat products. Meat Sci. 70, 493-508. doi:10.1016/j.meatsci.2004.11.021

Van Boekel, M.A.J.S., 2008. Kinetic Modeling of Food Quality: A Critical Review. Compr. Rev. Food Sci. Food Saf. 7, 144-158. doi:10.1111/j.1541-4337.2007.00036.x

Van Boekel, M.A.J.S., 1996. Statistical aspects of kinetic modeling for food science problems. J. Food Sci. 61, 477-485. doi:10.1111/j.1365-2621.1996.tb13138.x

van der Sman, R.G.M., 2013. Modeling cooking of chicken meat in industrial tunnel ovens with the Flory-Rehner theory. Meat Sci. 95, 940-957. doi:10.1016/j.meatsci.2013.03.027

Wattanachant, S., Benjakul, S., Ledward, D.A., 2005. Effect of heat treatment on changes in texture, structure and properties of Thai indigenous chicken muscle. Food Chem. 93, 337-348. doi:10.1016/j.foodchem.2004.09.032 